\title{
PREPARATION OF PAHAE NATURAL ZEOLITE NANOPARTICLES USING HIGH ENERGY MILLING AND ITS POTENTIAL FOR BIOETHANOL PURIFICATION
}

\author{
Susilawati $^{1,2,}{ }^{凶}$, Nasruddin M. N. ${ }^{1}$, Yuan Alfinsyah Sihombing ${ }^{1,2}$, Sri Ningsih \\ Yazana Pakpahan ${ }^{1}$, and Bonar Ferdiansyah ${ }^{1}$ \\ ${ }^{1}$ Department of Physics, Faculty of Mathematics and Natural Sciences, Universitas Sumatera \\ Utara, Medan, 20155, Indonesia. \\ ${ }^{2}$ Pusat Unggulan Iptek (PUI) Kitosan dan Material Maju, Universitas Sumatera Utara, \\ Medan, 20155, Indonesia \\ ${ }^{\square}$ Corresponding Author: susilawati@usu.ac.id
}

\begin{abstract}
The utilization of natural zeolite as an adsorbent has taken much attention, especially on its ability for bioethanol purification. However, the purification of bioethanol using micro-size zeolite-based adsorbent only resulted in an insignificant increase in bioethanol concentration. Finding a new technique that can improve bioethanol concentration is quite needed. A necessary correlation between surface area and diameter size of the particle could be an excellent way to resolve this issue. The objective of this study was to prepare natural zeolite nanoparticles obtained from Pahae District using a technique so-called high energy milling (HEM) and to investigate its effectiveness for improving the concentration of bioethanol. In this study, unmilled zeolite of 44 microns size (325 mesh), was used as a comparison. The result of PSA and BET confirmed the advancement of HEM technique for obtaining nano-zeolite, which improved the surface area of the particle, but on the other hand, reduced the pore volume and diameter. The comparison material showed that it has a greater porosity than the prepared nano-zeolite. Gas chromatography analysis showed that nano-zeolite was able to be used to improve the concentration of bioethanol. This study concluded that zeolite-based adsorbent, which has nanosized, gave a more reliable result than the micro-size due to the enhancement of the surface area of the particle.

Keywords: Nanoparticle, Pahae Natural Zeolite, High Energy Milling, Adsorbent, Bioethanol Purification.
\end{abstract}

RASĀYAN J. Chem., Vol. 14, No.2, 2021

\section{INTRODUCTION}

Zeolite has known as a porous material, it has several practical applications, e.g., as a filter or water vapor adsorbent, polymer electrolyte membranes, and the size of zeolite plays an essential role in the water vapor absorption rate ${ }^{1-4}$. In the previous study, Pahae natural zeolite, which has 200 mesh had higher water vapor adsorption capacity than Cikalong natural zeolite. With the high adsorption capacity of Pahae natural zeolite, this porous material can be a promising material as adsorbent ${ }^{1}$. A filter-based composite prepared from Pahae natural zeolite and cocoa shells showed an improvement in the adsorption capability from 25 to $53.82 \%{ }^{2}$. Another study using Pahae natural zeolite was focused on bioethanol purification using distillation and adsorption techniques ${ }^{3}$. The activated Pahae natural zeolite was able to adsorb water up to $53.82 \%$. It was able to improve the bioethanol concentration up to $93.28 \%$ with a contact time of 60 $\min ^{3}$.

The particle size of zeolite influences its adsorption capability, the smaller the zeolite particle size, the greater the surface area available for the adsorption, and this will affect the adsorption rate of material ${ }^{5}$. The activation process also plays an essential role in the effectiveness of zeolite capability. The effectiveness of zeolite's adsorption depends on the number and size of the opened pore that available on the surface of zeolite ${ }^{6}$. In Indonesia, as an abundant mineral, zeolite is constructed by anionic aluminosilicate as the primary building unit. 
This study aimed to prepare Pahae natural zeolite nanoparticles and to characterize their effectiveness for purifying bioethanol. Several characterizations were already performed for determining the characteristic of the obtained Pahae natural zeolite nanoparticle, i.e., water absorption, SEM, TEM, EDX, XRD, BET, PSA, and GC.

\section{Material}

\section{EXPERIMENTAL}

Pahae natural zeolite was obtained from Pahae District, Tapanuli Utara, Sumatera Utara, Indonesia, Sulphuric acid $96 \%$ was purchased from Mallinckrodt Lab Guard. Bioethanol which has $40 \%$ of concentration was provided by CV. Rudang Jaya. Ethanol of $96 \%$ was purchased from CV. Ampapaga.

\section{Pahae Natural Zeolite Nanoparticle Preparation}

Pahae natural zeolite nanoparticle was prepared using High Energy Milling (HEM E3D). Every $4.84 \mathrm{~g}$ of Pahae natural zeolite that was placed in the jar of HEM E3D was treated with 11 milling ball which weights $3.52 \mathrm{~g}$ of each ball ${ }^{7}$. Pahae natural zeolite that was not passed into the milling process was used as a comparison material which has 325 mesh of size. Both types of Pahae natural zeolite were chemically activated using sulfuric acid of $6 \%$ and the suspension was stirred at $70^{\circ} \mathrm{C}$. After $4 \mathrm{~h}$, Pahae natural zeolite was washed until the $\mathrm{pH}$ was neutralized and was dried in the oven at $100^{\circ} \mathrm{C}$ for one hour. The activated Pahae natural zeolite was then furnaced at 700,800 , and $900^{\circ} \mathrm{C}$ for $4 \mathrm{~h}^{3}$.

\section{Characterization}

Water sorption of the material was evaluated using ASTM C20-00, and it can be calculated by weighing the mass of material before and after soaking in water (Eq.-1).

$$
\% \text { Water Adsorption Capacity }=\left(\frac{\text { Final Mass-Initial Mass }}{\text { Initial Mass }}\right) \times 100 \%
$$

Bioethanol purification was performed using two different sizes of Pahae natural zeolite, i.e. 325 mesh and nanosize zeolite. About $50 \mathrm{~g}$ of Pahae natural zeolite was placed in beaker glass, and about $100 \mathrm{~mL}$ of bioethanol $40 \%$ was poured into beaker glass. While being stirred at $7 \mathrm{rpm}$ under different contact times, i.e., 30, 45, 60, 75, and $90 \mathrm{~min}$, the bioethanol was then evaporated using Rotary Evaporator with the rotation speed of $110-120 \mathrm{rpm}$ at $78^{\circ} \mathrm{C}$. The evaporated bioethanol was then analyzed using gas chromatography. The obtained concentration was then compared with ethanol $96 \%{ }^{3}$.

\section{Water Adsorption Capacity}

\section{RESULTS AND DISCUSSION}

The water adsorption capacity of Pahae natural zeolite was performed by following ASTM C20-00 and the result was shown in Fig.-1.

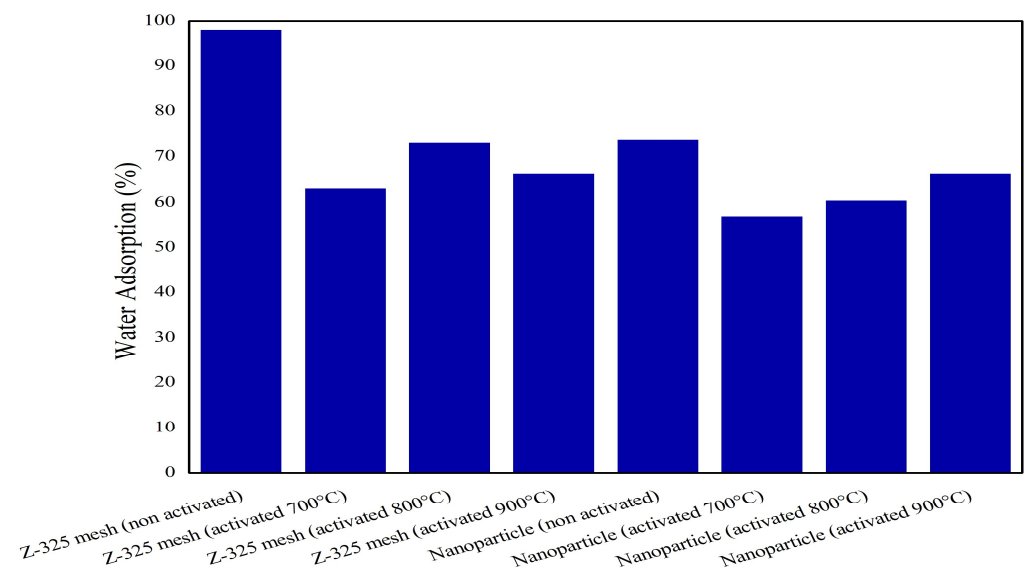

Fig.-1: Correlation between Activated Temperature and Water Adsorption Capacity 
RASĀYAN J. Chem.

Vol. 14 | No. 2 |1265-1272| April - June | 2021

Figure-1 shows that non-activated Pahae natural zeolite which had 325 mesh of size had the highest water adsorption capacity, and the lowest one was shown by activated Pahae natural zeolite nanoparticle at $700^{\circ} \mathrm{C}$, with the value of $98.29 \%$ and $57.02 \%$, respectively. These results concluded that non-activated Pahae natural zeolite had the highest water adsorption capacity than others prepared zeolite nanoparticles. The zeolite particle size influences the selectivity of zeolite, which molecules are allowed or disallowed to fill the zeolite pores. The smaller the zeolite particle, the more selective the adsorption on the surface of zeolite. $^{8}$

\section{Morphological Analysis}

The morphological of activated and non-activated zeolite which had 325 mesh of size that captured using a scanning electron microscope (SEM) can be seen in Fig.-2.

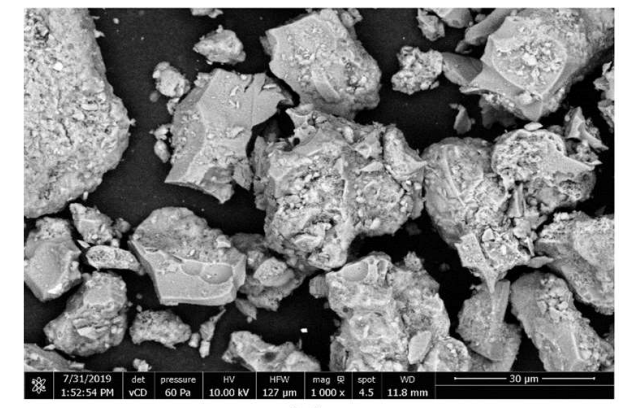

(a)

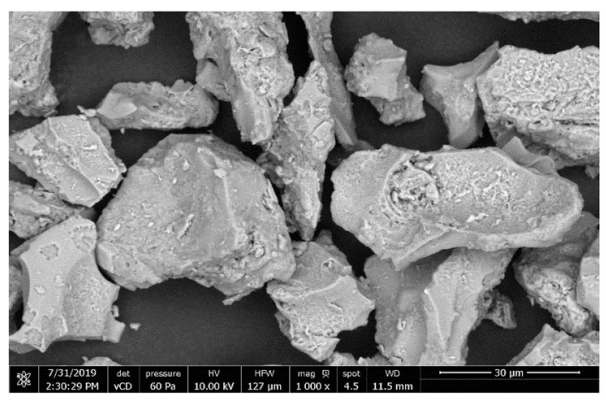

(c)

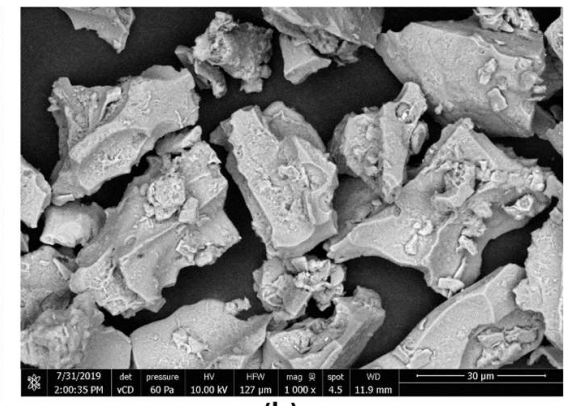

(b)

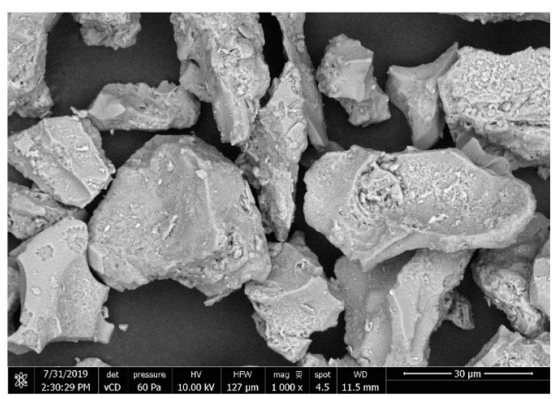

(d)

Fig.-2: Morphological of Pahae Natural Zeolite Surface -325 mesh: (a) Non-activated, activated at (b) $700^{\circ} \mathrm{C},(\mathrm{c})$ $800^{\circ} \mathrm{C}$, and (d) $900^{\circ} \mathrm{C}$

Based on the SEM images (Fig.-2a), the contaminant can still be found at non-activated Pahae natural zeolite. The cleanest morphological surface was obtained after being activated at $700-900^{\circ} \mathrm{C}$ (Fig. $-2 \mathrm{~b}$ to d). A similar result was also found in the previous study, the cleanest surface was obtained after activating process. ${ }^{9}$ The non-activated zeolite had crumbly and amorphous characteristics. A different result was obtained after the zeolite was activated, impregnated, and calcinated; lamellar pores structured was obtained..$^{10}$ This showed that the porous particle had a higher surface area and more potential as an adsorbent ${ }^{11}$. There is a strong correlation between the surface area of the adsorbent and the adsorption efficiency. ${ }^{12}$

The morphological structure of Pahae natural zeolite nanoparticle was captured using Transmission Electron Microscopy (TEM). Figure-3 shows the morphological of activated and non-activated zeolite nanoparticles. The non-activated zeolite nanoparticle image had dark color in several parts indicating the presence of contaminants, while the activated zeolite at $700-900^{\circ} \mathrm{C}$ has less contaminant that concluded from the less presence of dark color. ${ }^{9}$ The activating process is an important process that influences the adsorbent properties. ${ }^{13}$ The dark color can also be caused by the agglomerate formation due to the hydrophilic properties of zeolite ${ }^{14}$. Zeolite which has a smaller particle size will have a higher surface area 
RASĀYAN J. Chem.

Vol. 14 | No. 2 |1265-1272| April - June | 2021

and has high potential as an adsorbent, because the surface area of adsorbent plays an important role, especially on the adsorption efficiency. ${ }^{12}$

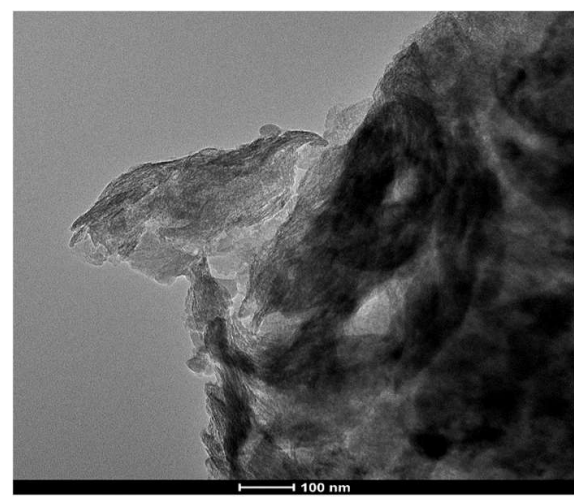

(a)

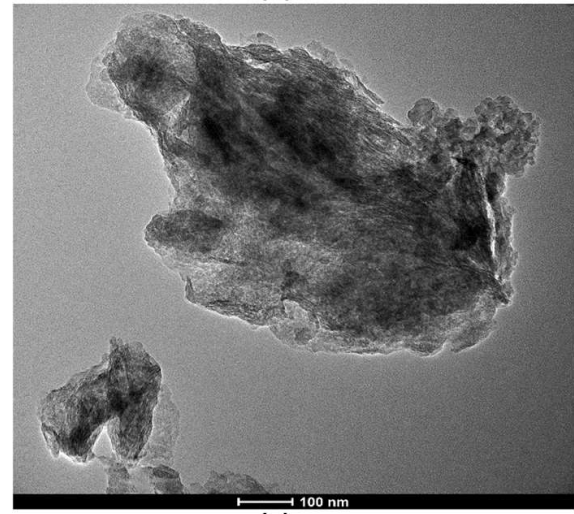

(c)

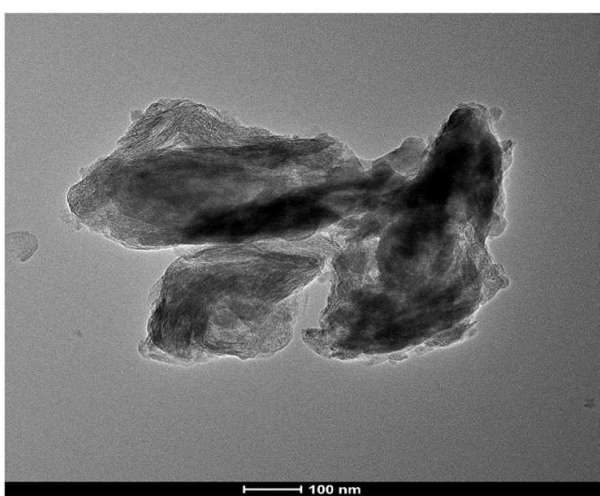

(b)

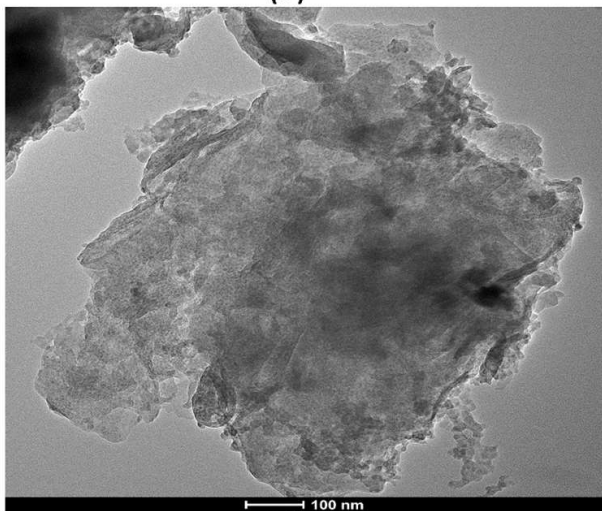

(d)

Fig.-3: Morphological Structure of Pahae Natural Zeolite Nanoparticle: (a) Non-activated; activated at (b) $700^{\circ} \mathrm{C}$, (c)

\section{EDX Analysis}

$800^{\circ} \mathrm{C}$, and (d) $900^{\circ} \mathrm{C}$

Zeolite is constructed by several elements, i.e., silicon, aluminum, oxygen, etc and binded several water molecules in its pores. Other elements that could be found in the zeolite structure are alkaline and alkaline earth metal groups. The non-activated Pahae natural zeolite which had 325 mesh of size was dominated by the presence of oxygen $(51.3 \%)$, silica $(22.1 \%)$, carbon $(13.2 \%)$, and aluminum $(6.8 \%)$ with the $\mathrm{Si} / \mathrm{Al}$ ratio was about 3.25. Meanwhile, the Si/Al ratio of activated Pahae natural zeolite 325 mesh at 700, 800, and $900^{\circ} \mathrm{C}$ were about $3.25,2.64$, and 3.57 , respectively. The atomic composition of each activated zeolite 325 mesh can be found in Table-1.

Table-1: Elemental Composition of Activated Pahae Natural Zeolite-325 Mesh

\begin{tabular}{c|c|c|c}
\hline Atom & $700^{\circ} \mathrm{C}($ wt. $\%)$ & $800^{\circ} \mathrm{C}($ wt. $\%)$ & $900^{\circ} \mathrm{C}(w t . \%)$ \\
\hline $\mathrm{O}$ & 45.2 & 47.6 & 46.5 \\
\hline $\mathrm{Si}$ & 26.0 & 27.2 & 26.8 \\
\hline $\mathrm{C}$ & 11.7 & 6.0 & 10.3 \\
\hline $\mathrm{Al}$ & 8.0 & 10.3 & 7.5 \\
\hline
\end{tabular}

The $\mathrm{Si} / \mathrm{Al}$ ratio of non-activated zeolite nanoparticles was about 3.86 with the atomic composition: oxygen (45.85\%), silica (25.47\%), carbon (15.88\%), aluminum (6.59\%). Meanwhile, the Si/Al ratio of activated Pahae natural zeolite nanoparticles at 700,800 , and $900^{\circ} \mathrm{C}$ were about $5.41,6.22$, and 3.70, respectively. The atomic composition of each activated zeolite nanoparticle can be found in Table- 2 .

The decrease of $\mathrm{Al}$ content in the zeolite was affected by the dealumination of zeolite ${ }^{15}$ and it improved the hydrophilic properties of zeolite. ${ }^{16,17}$ The lower the Al content in zeolite, the more enhance the Si/Al ratio. This phenomenon can be caused by the addition of sulfuric acid during the preparation. ${ }^{9,18}$ Zeolite with high Si content will have hydrophobic properties and a high affinity to the hydrocarbon. ${ }^{19}$ The 
RASĀYAN J. Chem.

Vol. 14 | No. 2 |1265-1272| April - June | 2021

presence of carbon atom in zeolite is predicted can adsorb gas, i.e., water vapor. Based on the $\mathrm{Si} / \mathrm{Al}$ ratio of Pahae natural zeolite, Pahae natural zeolite can be categorized as modernite type which has the intermediate capability to adsorb water. This result was supported by the previous studies that mentioned modernite type of zeolite can have a wide range of $\mathrm{Si} / \mathrm{Al}$ ratio, i.e., 4.4-5.5 $5^{20}$ and 6.6-10.5. ${ }^{17}$ Another study confirmed that zeolite with the small $\mathrm{Si} / \mathrm{Al}$ ratio showed a strong affinity to water and ethanol molecules proven by the better result of water adsorption study than using zeolite which has high $\mathrm{Si} / \mathrm{Al}$ ratio. ${ }^{21}$

Table-2: Elemental Composition of Activated Pahae Natural Zeolite Nanoparticle

\begin{tabular}{c|c|c|c}
\hline Atom & $700^{\circ} \mathrm{C}($ wt. $\%)$ & $800^{\circ} \mathrm{C}($ wt. $\%)$ & $900^{\circ} \mathrm{C}$ (wt.\%) \\
\hline $\mathrm{O}$ & 48.73 & 46.88 & 50.04 \\
\hline $\mathrm{Si}$ & 29.75 & 29.45 & 32.27 \\
\hline $\mathrm{C}$ & 9.81 & 13.03 & 8.98 \\
\hline $\mathrm{Al}$ & 5.49 & 4.73 & 8.71 \\
\hline
\end{tabular}

\section{X-Ray Diffraction (XRD) Analysis}

X-Ray Diffraction (XRD) analysis of zeolite can be used to determine the presence of crystalline and amorphous regions on its structure. Figure- 4 shows the diffractogram of activated and non-activated Pahae natural zeolite 325 mesh and nanoparticle.

Rietveld analysis on the diffractogram of Pahae natural zeolite (Fig.-4) confirmed that non-activated and activated Pahae natural zeolite nanoparticle at $700^{\circ} \mathrm{C}$ was consisted of two types of zeolite, i.e., modernite and keatite, while the other activated Pahae natural zeolite nanoparticle was only consisted by modernite type. The lattice crystal information of modernite and keatite type zeolite can be seen in Table-3.
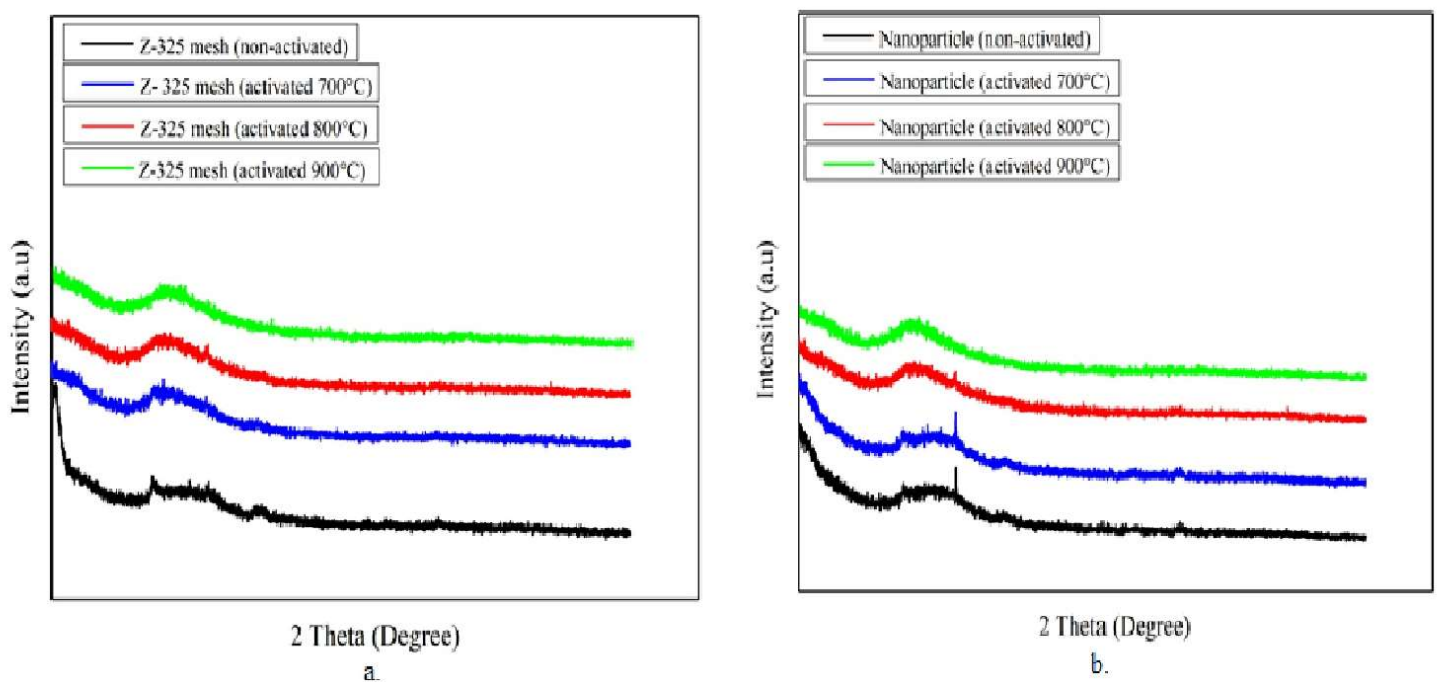

Fig.-4: Diffractogram of Pahae Natural Zeolite (a) 325 mesh: non-activated, activated at $700^{\circ} \mathrm{C}, 800^{\circ} \mathrm{C}$, and $900^{\circ} \mathrm{C}$, (b) Nanoparticle: non-activated, activated at $700^{\circ} \mathrm{C}, 800^{\circ} \mathrm{C}$, and $900^{\circ} \mathrm{C}$.

Table-3: Lattice Crystal of Pahae Natural Zeolite

\begin{tabular}{l|l}
\hline Mineral Name: & Mordenite \\
Chemical Formula: & $\mathrm{Al}_{1.956} \mathrm{Ca}_{0.466} \mathrm{H}_{34} \mathrm{~K}_{0.24} \mathrm{Na}_{0.69} \mathrm{O}_{31.18} \mathrm{Si}_{10.044}$ \\
Crystal System: & Orthorhombic \\
\hline Space Group: & $\mathrm{C} \mathrm{m} \mathrm{c} 2_{1}$ \\
\hline Mineral Name: & Keatite \\
Chemical Formula: & $\mathrm{SiO}_{2}$ \\
Crystal System: & Tetragonal \\
\hline Space Group: & $\mathrm{P} 4_{1} 2_{1} 2$ \\
\hline
\end{tabular}

The previous study showed that zeolite can be constructed by several types of mineral, i.e., mordenite with $2 \theta=25.6405^{\circ}$ and $2 \theta=27.7193^{\circ}$, clinoptilolite with $2 \theta=22.2211^{\circ}$, quart was also found in the 
RASĀYAN J. Chem.

zeolite with $2 \theta=26.2564^{\circ}$ and montmorillonite with $2 \theta=21.8120^{\circ} . .^{22}$ The obtained diffractogram of zeolite in this study showed the presence of amorphous structure ${ }^{23}$ due to HEM treatment that was used in this study transformed the zeolite granules into fine powder. This process caused the decrease of zeolite crystallinity or the level of the order became smaller and there were more diffraction collisions due to the diffractogram become thickened. ${ }^{19}$ This result was supported by a study stating that the fresh zeolite (without activation treatment) showed a high crystallinity property than the activated zeolite. ${ }^{24}$

\section{Brunauer Emmett Teller (BET) Analysis}

The BET analysis on activated and non-activated Pahae natural zeolite was performed to determine the surface area, pore radius, and pore volume that present in the treated zeolite. The BET result can be seen in Table-4.

Table-4: BET Result of Pahae Natural Zeolite 325 mesh and Nanoparticle

\begin{tabular}{c|l|c|c|c}
\hline No. & \multicolumn{1}{|c|}{ Treatments } & Surface Area $\left(\mathrm{m}^{2} / \mathrm{g}\right)$ & Pore Volume $(\mathrm{cc} / \mathrm{g})$ & Pore Radius $(\AA)$ \\
\hline 1. & 325 mesh (non-activated) & 14.479 & 0.031 & 16.366 \\
\hline 2. & 325 mesh $\left(\right.$ activated $\left.700^{\circ} \mathrm{C}\right)$ & 9.955 & 0.020 & 16.289 \\
\hline 3. & 325 mesh $\left(\right.$ activated $\left.800^{\circ} \mathrm{C}\right)$ & 10.570 & 0.026 & 18.165 \\
\hline 4. & 325 mesh $\left(\right.$ activated $\left.900^{\circ} \mathrm{C}\right)$ & 2.298 & 0.010 & 64.206 \\
\hline 5. & Nanoparticle (non-activated) & 17.687 & 0.035 & 16.321 \\
\hline 6. & Nanoparticle $\left(\right.$ activated $\left.700^{\circ} \mathrm{C}\right)$ & 20.721 & 0.041 & 16.283 \\
\hline 7. & Nanoparticle $\left(\right.$ activated $\left.800^{\circ} \mathrm{C}\right)$ & 17.474 & 0.039 & 16.281 \\
\hline 8. & Nanoparticle $\left(\right.$ activated $\left.900^{\circ} \mathrm{C}\right)$ & 3.969 & 0.010 & 16.369 \\
\hline
\end{tabular}

Table-4 shows non-activated Pahae natural zeolite 325 mesh had higher surface area and pore volume than the activated Pahae natural zeolite of 325 mesh. On the other hand, the activated Pahae natural zeolite at $700^{\circ} \mathrm{C}$ showed a higher surface area and pore volume than the other treated Pahae natural zeolite nanoparticle. The agglomeration that might occur during the physical activation can be the main reason for this phenomenon. The previous study showed a similar phenomenon where the higher surface area was found at the zeolite which had a particle size of $38 \mu \mathrm{m}$ (400 mesh) than zeolite that had a particle size of $75 \mu \mathrm{m}(200 \mathrm{mesh}) .{ }^{16}$ Agglomeration is a unification of small particles to create bigger particles through physical interaction. Agglomeration also caused data misinterpretation, i.e., specific surface area, due to the gas adsorption during the BET analysis occurred in the agglomerate particle, not in the single-particle of zeolite. ${ }^{7}$

\section{Particle Size Analyzer (PSA) Analysis}

Table-5 shows the average diameter of all treated Pahae natural zeolite that was determined using PSA. Non-activated Pahae natural zeolite nanoparticles had the smallest diameter which about $118 \mathrm{~nm}$. However, a different result was obtained on the Pahae natural zeolite of 325 mesh, the activated zeolite at $800^{\circ} \mathrm{C}$ has the smallest diameter, which about $251.9 \mathrm{~nm}$. The HEM treatment plays an important role during the physical treatment, especially $10 \mathrm{~h}$ of the milling contact time can improve the effectiveness of particle collisions for obtaining particle with nanosize. ${ }^{25}$ The top-down method using HEM can cause agglomeration if the process is done excessively.

Tabel-5: The Average Diameter of all treated Pahae Natural Zeolite

\begin{tabular}{c|c|c}
\hline No. & Treatments & Average Diameter $(\mathrm{nm})$ \\
\hline 1. & 325 mesh (non-activated) & 274.6 \\
\hline 2. & 325 mesh (activated $\left.700^{\circ} \mathrm{C}\right)$ & 814.1 \\
\hline 3. & 325 mesh $\left(\right.$ activated $\left.800^{\circ} \mathrm{C}\right)$ & 251.9 \\
\hline 4. & 325 mesh $\left(\right.$ activated $\left.900^{\circ} \mathrm{C}\right)$ & 1499.0 \\
\hline 5. & Nanoparticle (non-activated) & 118.4 \\
\hline 6. & Nanoparticle (activated $\left.700^{\circ} \mathrm{C}\right)$ & 306.8 \\
\hline 7. & Nanoparticle (activated $\left.800^{\circ} \mathrm{C}\right)$ & 1074.7 \\
\hline 8. & Nanoparticle $\left(\right.$ activated $\left.900^{\circ} \mathrm{C}\right)$ & 637.4 \\
\hline
\end{tabular}

The increase of activation temperature can induce the increase in diameter of zeolite particles due to the solidification of the sintering effect. The desorption of $\mathrm{Si}$ and $\mathrm{Al}$ atom has an important contribution to 
RASĀYAN J. Chem.

Vol. 14 | No. 2 |1265-1272| April - June | 2021

enhancing the porosity of zeolite, but due to the sintering effect, the result of this desorption effect cannot be seen. As the result, the higher diameter of zeolite particle was obtained at higher activation temperature. ${ }^{26,27}$

\section{Bioethanol Purification}

Gas chromatography analysis was performed to determine the purity level of bioethanol after treated with Pahae natural zeolite of 325 mesh and nanoparticle, and evaporating process. Table-6 shows the concentration of bioethanol after treatments.

Table-6: Bioethanol Concentration after treating with Pahae Natural Zeolite 325 mesh and Nanoparticle

\begin{tabular}{|c|c|c|c|c|c|}
\hline No. & Zeolite & $\begin{array}{l}\text { Contact } \\
\text { Time }\end{array}$ & $\begin{array}{l}\text { Initial Bioethanol } \\
\text { Concentration }(\%)\end{array}$ & $\begin{array}{c}\text { Final Bioethanol } \\
\text { Concentration }(\%)\end{array}$ & $\begin{array}{c}\text { The increase of Bioethanol } \\
\text { Concentration }(\%)\end{array}$ \\
\hline 1. & \multirow{5}{*}{325 mesh } & $30 \mathrm{~min}$ & 40 & 54.751 & 36.877 \\
\hline 2. & & $45 \mathrm{~min}$ & 40 & 52.626 & 31.565 \\
\hline 3. & & $60 \mathrm{~min}$ & 40 & 52.518 & 31.295 \\
\hline 4. & & $75 \mathrm{~min}$ & 40 & 46.503 & 16.257 \\
\hline 5. & & $90 \mathrm{~min}$ & 40 & 43.293 & 8.232 \\
\hline 6. & \multirow{5}{*}{ nanoparticle } & $30 \mathrm{~min}$ & 40 & 48.490 & 21.225 \\
\hline 7. & & $45 \mathrm{~min}$ & 40 & 75.591 & 88.977 \\
\hline 8. & & $60 \mathrm{~min}$ & 40 & 50.427 & 26.067 \\
\hline 9. & & $75 \mathrm{~min}$ & 40 & 49.052 & 22.630 \\
\hline 10. & & $90 \mathrm{~min}$ & 40 & 47.975 & 19.937 \\
\hline
\end{tabular}

The optimum result of bioethanol concentration was found at the 45 min of contact time using Pahae natural zeolite nanoparticle, with the increase in bioethanol concentration was about $88.97 \%$. This result was supported with the PSA and BET result, where this treated zeolite has a smaller particle size than Pahae natural zeolite $325 \mathrm{mesh}$, i.e., $118.4 \mathrm{~nm}$, and the higher surface area, i.e., $17.687 \mathrm{~m}^{2} / \mathrm{g}$. The contact time of zeolite with bioethanol influences the final concentration of bioethanol. The longer the contact time the more water and bioethanol that will be adsorbed on the zeolite surface, this caused a decrease in the increase of bioethanol concentration.

\section{CONCLUSION}

Pahae natural zeolite nanoparticles can improve the water adsorption capacity during bioethanol purification. This can be seen in the PSA analysis, the treated zeolite has $118.4 \mathrm{~nm}$ of particle size and $17.687 \mathrm{~m}^{2} / \mathrm{g}$ of the surface area using BET. The ratio of Si/Al from EDX analysis confirms the presence of modernite in the Pahae natural zeolite, and this is supported by XRD analysis that confirms the presence of modernite and keatite. The treated Pahae natural zeolite nanoparticle has the potential to adsorb water vapor in bioethanol products. There is a significant result during the water vapor adsorption, the nanoparticle zeolite can increase the concentration of bioethanol up to $88.977 \%$, while the zeolite 325 mesh is only $36.877 \%$.

\section{ACKNOWLEDGEMENT}

The authors are very grateful to Universitas Sumatera Utara for its funding throughout the TALENTA research program 2019 with given contract numbers 4167/UN5.1.R/PPM/2019 on 01 April 2019.

\section{REFERENCES}

1. T.I. Nasution, Susilawati, F. Zebua, H. Nainggolan, and I. Nainggolan, Applied Mechanics and Materials, 754-755, 789(2015), DOI:10.4028/www.scientific.net/AMM.754-755.789

2. Susilawati, T.I. Nasution, F. Zebua, and H. Nainggolan, International Journal of Applied Engineering Research, 12(13), 3914(2017)

3. Susilawati, M.N. Nasruddin, C. Kurniawan, I. Nainggolan, and Y.A. Sihombing, Journal of Physics: Conference Series, 1116(3), 032037(2018), DOI:10.1088/1742-6596/1116/3/032037

4. Y.A. Sihombing, Susilawati, S.U. Rahayu, and A. Siahaan, Rasayan Journal of Chemistry, 13(4), 2181(2020), DOI:10.31788/RJC.2020.1345906 
RASĀYAN J. Chem.

Vol. 14 | No. 2 |1265-1272| April - June | 2021

5. A. Yamliha, B.D. Argo, and W.A. Nugroho, Jurnal Bioproses Komoditas Tropis, 1(2), 67(2013)

6. E. Heraldy, H.S.W, and Sulistiyono, Indonesian Journal of Chemistry, 3(2), 91(2003)

7. M. Muhriz, A. Subagio, and Pardoyo, Jurnal Sains dan Matematika, 19(1), 11(2011)

8. R. Wulandari, and C. Priyono, Indonesian Journal on Medical Science, 1(2), 60(2014)

9. T. Las, F. Firdiyono, and A. Hendrawan, Valensi, 2(2), 368(2011)

10. T. E. Suharto, I. Gustian, and A. Sundaryono, Jurnal Gradien, 3(2), 267(2007)

11. B. Hastuti, S. Hadi, and W. Purwendah, International Journal on Advanced Science Engineering Information Technology, 10(1), 351(2020), DOI:10.18517/ijaseit.10.1.10655

12. H. Javadian, F. Ghorbani, H.-a. Tayebi, and S.M.H. Asl, Arabian Journal of Chemistry, 8(6), 837(2015), DOI: 10.1016/j.arabjc.2013.02.018

13. F. Azima, N. Nazir, and N.P. Sari, International Journal on Advanced Science Engineering Information Technology, 7(3), 916(2017), DOI:10.18517/ijaseit.7.3.1084

14. F. Gultom, B. Wirjosentono, Thamrin, H. Nainggolan, and Eddiyanto, Procedia Chemistry, 19, 1007(2016), DOI:10.1016/j.proche.2016.03.150

15. A. Ates, Journal of Colloid and Interface Science, 523(1), 266(2018), DOI: $10.1016 /$ j.jcis.2018.03.115

16. L. Sentosa, B.S. Subagio, H. Rahman, and R.A. Yamin, Jurnal Teknik Sipil, 25(3), (2018), DOI: 10.5614 /jts.2018.25.3.5

17. C.D. Smedt, F. Ferrer, K. Leus, and P. Spanoghe, Adsorption Science \& Technology, 33(5), 457(2015), DOI: 10.1260/0263-6174.33.5.457

18. S.K. Wahono, J. Stalin, J. Addai-Mensah, W. Skinner, A. Vinu, and K. Vasilev, Microporous and Mesoporous Materials, 294, 109871(2020), DOI:10.1016/j.micromeso.2019.109871

19. M. Sirait, N. Bukit, and U. Simarmata, Jurnal Sains Materi Indonesia, 16(1), 7(2014)

20. M.W. Ackley, S.U. Rege, and H. Saxena, Microporous and Mesoporous Materials, 61(1-3), 25(2003), DOI:10.1016/S1387-1811(03)00353-6

21. T. Yamamoto, Y.H. Kim, B.C. Kim, A. Endo, N. Thongprachan, and T. Ohmori, Chemical Engineering Journal, 181-182, 443(2012), DOI:10.1016/j.cej.2011.11.110

22. A.W. Ningsih, E.M. Tamboesai, and A. Muchtar, Jurnal Photon, 6(1), 97(2015)

23. Susilawati, T.I. Nasution, and S. Khanifah, Rasayan Journal of Chemistry,13(3), 1785(2020), DOI:10.31788/ RJC.2020.1335678

24. D.J.C. Yates, Canadian Journal of Chemistry, 46(10), 1695(1968), DOI:10.1139/v68-282

25. S. Mustafa, S.B. Widjanarko, Jurnal Pangan dan Agroindustri 3(2), 560(2015)

26. E. Wibowo, M. Rokhmat, S. Sutisna, K. Khairurrijal, and M. Abdullah, Jurnal Matematika dan Sains, 22(1), 37(2017), DOI:10.5614/jms.2017.22.1.10

27. I. Gustian, Ghufira, and D. Oktiarni, Rasayan Journal of Chemistry, 10(3), 689(2017), DOI: $10.7324 /$ RJC.2017.1031716

[RJC-6189/2020] 